\title{
Characterization and leaching of mechanically activated zinc residue
}

\author{
M. Deniz Turan ${ }^{1} \mathbb{0}$
}

Received: 2 July 2020 / Accepted: 23 December 2020 / Published online: 7 February 2021

(c) The Author(s) 2021

\begin{abstract}
Zinc extraction from zinc-containing residual (ZCR) was examined with the leach of sulfuric acid of original materials and the materials milled in two different mill systems. For this purpose, vibrating ball mill (VBM) and ring mill (RM) were used. In chemical analysis of $\mathrm{ZCR}$, it was determined that it contains a significant amount of zinc, lead, iron and silver and consisted of mostly $\mathrm{CaSO}_{4} \cdot 2 \mathrm{H}_{2} \mathrm{O}, \mathrm{PbO}, \mathrm{SiO}_{2}, \mathrm{Fe}_{2} \mathrm{O}_{3}, \mathrm{ZnFe}_{2} \mathrm{O}_{4}, \mathrm{Al}_{2} \mathrm{FeO}_{4}$ and $\mathrm{PbSO}_{4}$ mineral phases. It was determined in $\mathrm{XRD}$ analysis of samples milled at both mills that peak intensity dramatically decreased when compared to original sample. According to comparative characterization analyses of the milled samples, it was determined that through the increasing grinding time, the particles became agglomerated and an increase in grain size occurred. This situation was also supported by $\mathrm{N}_{2}$-BET and SEM analyses.

While zinc extraction value of the sample milled for $1 \mathrm{~min}$, which was obtained at $0.5 \mathrm{M} \mathrm{H}_{2} \mathrm{SO}_{4}$ at leach temperature of $25^{\circ} \mathrm{C}$, at the solid-liquid rate of 100:1 and during the leach time of $30 \mathrm{~min}$, was $90 \%$ and $60 \%$ for, respectively, VBM and $\mathrm{RM}$, zinc of $54 \%$ was determined to be extracted in the leach of the original sample, under the same conditions.
\end{abstract}

Keywords Zinc $\cdot$ Mechanical activation $\cdot$ Milling $\cdot$ Leaching $\cdot$ Hydrometallurgy

\section{Introduction}

Zinc metallurgy can be sorted a few section that contains pyrometallurgy, hydrometallurgy, or their combination processes. The most common zinc ore is the sulfide mineral of zinc that is called as sphalerite $(\mathrm{ZnS})$. Zinc nearly always occurs together with galena $(\mathrm{PbS})$ in the ore source, so that the metallurgical production of these two metals must be considered together. Raw ore is first crushed, milled and sieved following flotation where galena, sphalerite and gang minerals are separated as two concentrates and tailing. The sphalerite concentrate is roasted to obtain zinc oxide so that the zinc oxide can be leached in the presence of acid. During roasting, zinc ferrite may be formed if iron is present in the concentrate. Since iron is one of most common component present in the sphalerite concentrate, the formation of zinc ferrite is usually unavoidable. Zinc ferrite formation reaction may be represented as:

M. Deniz Turan

mdturan@firat.edu.tr

1 Department of Metallurgical and Materials Engineering, Firat University, 23119 Elazig, Turkey
$\mathrm{ZnS}+\mathrm{Fe}_{2} \mathrm{O}_{3}+3 / 2 \mathrm{O}_{2} \rightarrow \mathrm{ZnFe}_{2} \mathrm{O}_{4}+\mathrm{SO}_{2}$

The zinc ferrite $\left(\mathrm{ZnFe}_{2} \mathrm{O}_{4}\right)$ represented in Eq. 1 is actually a spinel compound $\left(\mathrm{ZnO} \cdot \mathrm{Fe}_{2} \mathrm{O}_{3}\right)$.

Zinc ferrite is not a problem for the pyrometallurgical recovery processes, because it is easy to decompose and can be reduced by carbon monoxide. However, zinc ferrite formation is a serious problem for the hydrometallurgical recovery processes, since it is insoluble in dilute sulfuric acid (Nunez and Vinals 1984; Xia and Pickles 1999; Turan et al. 2004; Zhang et al. 2016).

During filtration of the leaching slurry, the metal-ferrite structure passes to the filter cake that causing the enrichment a considerable amount of zinc, lead and even silver in residue.

In the recent studies, various extraction methods for recovery of valuable metals from zinc-containing residue (ZCR) was applied such as chloride leaching (Raghavan et al. 1998; Langova et al. 2009; Silwamba et al. 2020), two-stage leaching with sulphuric acid and citric acid (Fattahi et al. 2016; Sethurajan et al. 2017), sulfate roasting and water leaching (Jiang et al. 2017; Guo-min et al. 2017), using of membrane filter press (Ru et al. 2015), and converting by $\mathrm{SO}_{2}$ ( $\mathrm{Li}$ et al. 2020). On the other hand, mechanical 
activation/advanced milling is known as pre-treatment method for leaching studies.

Baláž (2000), as stated in his book (as a general approach), stated that primary effects of mechanical activation studies are known as a decrease in particle size change, an increase of surface area change, an increase in internal and surface energy, and a decrease in the coherence energy of the solid samples. Secondary processes that are observed as aggregation, adsorption and recrystallization can occur during and after milling (Baláž 2000; Haug 2010). During grinding in energy intensive mills, physico-chemical and structural properties of particles are changed. In this context, effect of mechanical activation was put frothed for various leaching studies such as pyrrhotite (Zhao et al. 2009), pentlandite concentrate (Baláž 2000), alkaline treatment of zinc plant residue (Ashtari and Pourghahramani, 2015), reduction of metal oxides (Tokumitsu, 1997), rare-earth elements (Tan et al. 2016), and waste management (Guo et al. 2010).

In this study, effect of mechanical activation using two different mills on the leaching of zinc from zinc-containing residue (ZCR) was investigated. For this purpose, two different milled material obtained from mills and original plant residue were leached with sulphuric acid solution, and results were compared.

\section{Materials and methods}

Zinc-containing residue (ZCR) was supplied from KayseriTurkey. Approximately $35 \mathrm{~kg}$ of zinc plant residue was supplied from the plant in accordance with the sampling methods. To reflect the actual condition, the supplied material was not comminuted further. Some lumps were cracked and dispersed with a slight pressing force using a glass baguette.

Elemental analysis of the residue and mineralogical composition of the sample were performed in ACME laboratory and $\mathrm{X}$-ray diffraction analysis, respectively. Image analysis of milled and non-milled samples were carried out SEM (JEOL-JSM-7001F, Japan).

$\mathrm{N}_{2}$-BET surface area measurements of the samples were performed with the ASAP 2020 instrument (Micromeritics Headquarters, USA).

Moreover, particle size distribution of the samples was determined using a Mastersizer-2000 laser size distribution analyzer (Malvern Instrument, UK).

Two different grinding system was used to elucidate the effect of mechanical activation on zinc leaching from ZCR. These grinding system are high speed vibrating ball mill
(VBM) and ring mill (RM). These grinding systems have different effect on particle such as VBM is having impact on particle and RM is having attrition effect for particles in grinding process.

High-speed vibrating ball mill (VBM) contained tungsten jar of $80 \mathrm{ml}$ volume and placed on a moving table of the device in which grinding process with a high speed (max $1200 \mathrm{rpm}$ ) has been performed. 8-mm and 4-mm diameter balls were fed into VBM jar performing milling. Ring mill (RM) having $660 \mathrm{~cm}^{3}$ volume of nested rings made from tungsten carbide. This ring mill consists of rings with 2 different diameters (external diameters $17.5 \mathrm{~cm}$ and $12.5 \mathrm{~cm}$ ) and cylinder (diameter $8.5 \mathrm{~cm}$ ) in the center. Grinding equipment was mounted on a moving table.

$10 \mathrm{~g}$ of fresh ZCR was fed to the mills for every new experiment and the milling material obtained was leached without waiting. The leaching experiments were performed using the material obtained from two different mills and the non-milled (original material) plant residue.

All leaching experiments were performed using a conventional magnetic multi stirrer (Velp Scientifica MultiStirrer 15).

Experiments were carried out in 200-mL flasks by stirring magnetically under the reflux.

After leaching, slurry was filtered and filter cake was washed with distilled water. The leachates were acidified with nitric acid to prevent precipitation of metals. The solutions were analyzed by AAS (Analyst-400).

\section{Results}

\section{Characterization of original ZCR}

Results of elemental analysis of the ZCR are shown in Table 1. According to the data in Table 1, ZCR contained various precious metals such as $7.98 \% \mathrm{Zn}, 15.02 \% \mathrm{~Pb}$, and $68.4 \mathrm{ppm} \mathrm{Ag}$. In particular, recovery of these metals using economical techniques is considered as a significant benefit due to reduction of metal losses and environmental risk. However, the biggest problem in hydrometallurgical recovery of zinc from ZCR is the presence of zinc ferrite structure (Turan et al. 2019).

The particle size distribution is important parameter for mechanical activation/extended milling studies. For this purpose, original particle size distribution of ZCR was determined in unit $\mu \mathrm{m}$ as $d(0.1)=3.176, d(0.5)=24.706$, and $d(0.9)=410.834$ (Fig. 1).
Table 1 Chemical composition of ZCR

\begin{tabular}{llllllllll}
\hline $\mathrm{Pb}$ & $\mathrm{Zn}$ & $\mathrm{Fe}$ & $\mathrm{Cu}$ & $\mathrm{Al}$ & $\mathrm{Sr}$ & $\mathrm{Si}$ & $\mathrm{Ca}$ & $\mathrm{Ag}$ & $\mathrm{Au}$ \\
\hline$\% 15.02$ & $\% 7.98$ & $\% 5.44$ & $\% 0.065$ & $\% 1.85$ & $\% 0.15$ & $\% 6.74$ & $\% 6.19$ & $68.4 \mathrm{ppm}$ & $15.7 \mathrm{ppb}$ \\
\hline
\end{tabular}


Fig. 1 Particle size distribution of ZCR

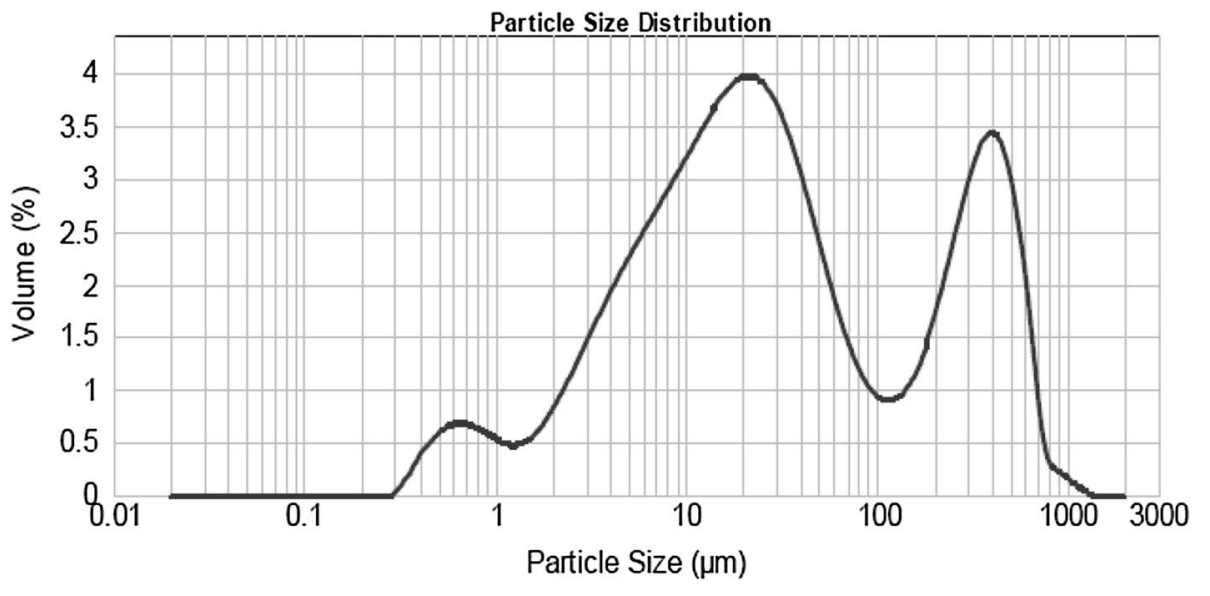

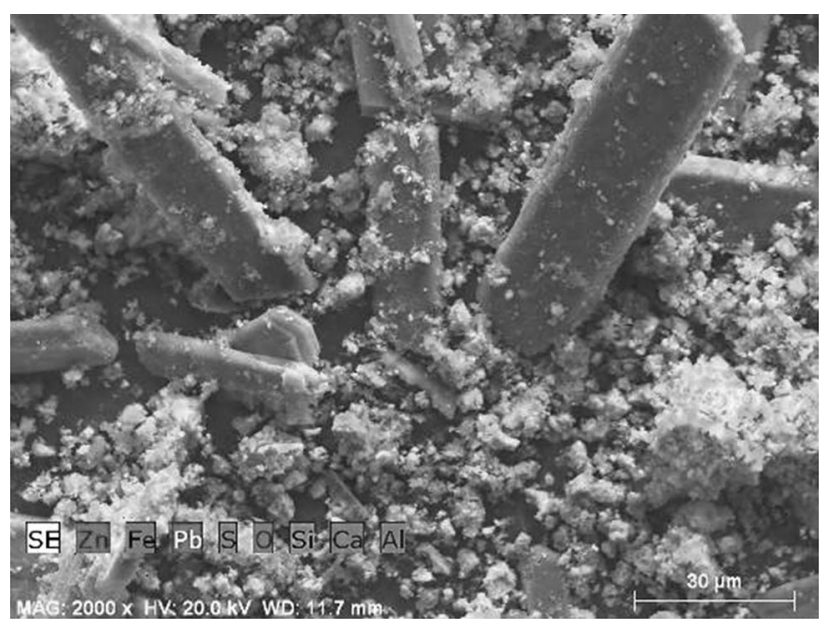

Fig. 2 SEM image of original ZCR

Moreover, Fig. 2 shows images obtained from (SEM) scanning electron microscopy of ZCR. Scanning electron microscopy images indicate that there were rod-shaped particles in the sample.

The particle surface area of the original ZCR was determined by $\mathrm{N}_{2}$-BET surface area measurement because of the changes in the particle surface area due to extended grinding. According to the results, the BET surface area of ZCR was almost $28.40 \pm 0.51 \mathrm{~m}^{2} / \mathrm{g}$.

\section{Characterization of the milled materials}

In the study, in which the effect of mechanical activation process on extraction efficiency of metals was examined, ZCR was subjected to grinding at vibrating ball mill (VBM) and ring mill (RM) for different times.

Every time, fresh feeding was provided to grinding system and the samples taken from mill at the end of grinding time were characterized. On the other hand, in the studies carried out to examine the effect of mechanical activation procedures carried out on the leach efficiency, it was done by weighing a suitable amount of materials taken from mill and by leaching it with sulfuric acid.

The XRD analysis of ZCR was carried out to determinate its phase composition. The XRD analysis showed that the dominant peaks belonged to gypsum $\left(\mathrm{CaSO}_{4} \cdot 2 \mathrm{H}_{2} \mathrm{O}\right)$ and anglesite $\left(\mathrm{PbSO}_{4}\right)$. Moreover, other mineral phases were determined as massicot $(\mathrm{PbO})$, quartz $\left(\mathrm{SiO}_{2}\right)$ and maghemite $\left(\mathrm{Fe}_{2} \mathrm{O}_{3}\right)$, and the zinc found in the residue was in the form of franklinite $\left(\mathrm{ZnFe}_{2} \mathrm{O}_{4}\right)$. ZCR was subjected to grinding in two different grinding systems in the range of 1-30 min. The obtained samples were characterized by carrying out various analyses and traces of mechanical activation were looked for. First, XRD analysis of each milled sample was taken for this and compared with the original peaks (Fig. 3).

In high-energy grinding systems, pulse applied to the material is expected to transfer some of mill energy to material to be ground, to cause various changes within material and to activate (Charlot et al. 1999; Chen et al. 2015). In addition to this, the changes in crystal lattice of material through long-term grinding procedures can be revealed through X-ray analysis (Pourghahramani and Akhgar 2015). As seem in the figures, Franklinite peaks are generally in tendency to decrease through the increasing grinding time. On the other hand, it is clearly seen that the peaks, representing Anglesite mineral phase obtained in different grinding times, have changed.

SEM analysis of samples obtained in different grinding times was carried out. Results of SEM analysis of samples, obtained at the end of the grinding time range of 1-30 min, are seen in Fig. 4. SEM analyses also support the changes of peaks mentioned above, such that especially small particles seem to stick to larger ones.

In advanced mechanical activation procedures, occurrence of the decrease in grain size of the ground material is basically an expected condition. Decrease in particle size plays an active role in the leaching to be carried out following grinding. Due to these reasons, PSD (Particle Size 
Fig. 3 Comparisons of XRD peaks of milled and original samples a original ZCR, b milled by VBM, c milled by

RM [Milling time for (b) and (c); black line: $1 \mathrm{~min}$, red line: $5 \mathrm{~min}$, blue line: $15 \mathrm{~min}$, green line: $30 \mathrm{~min}$
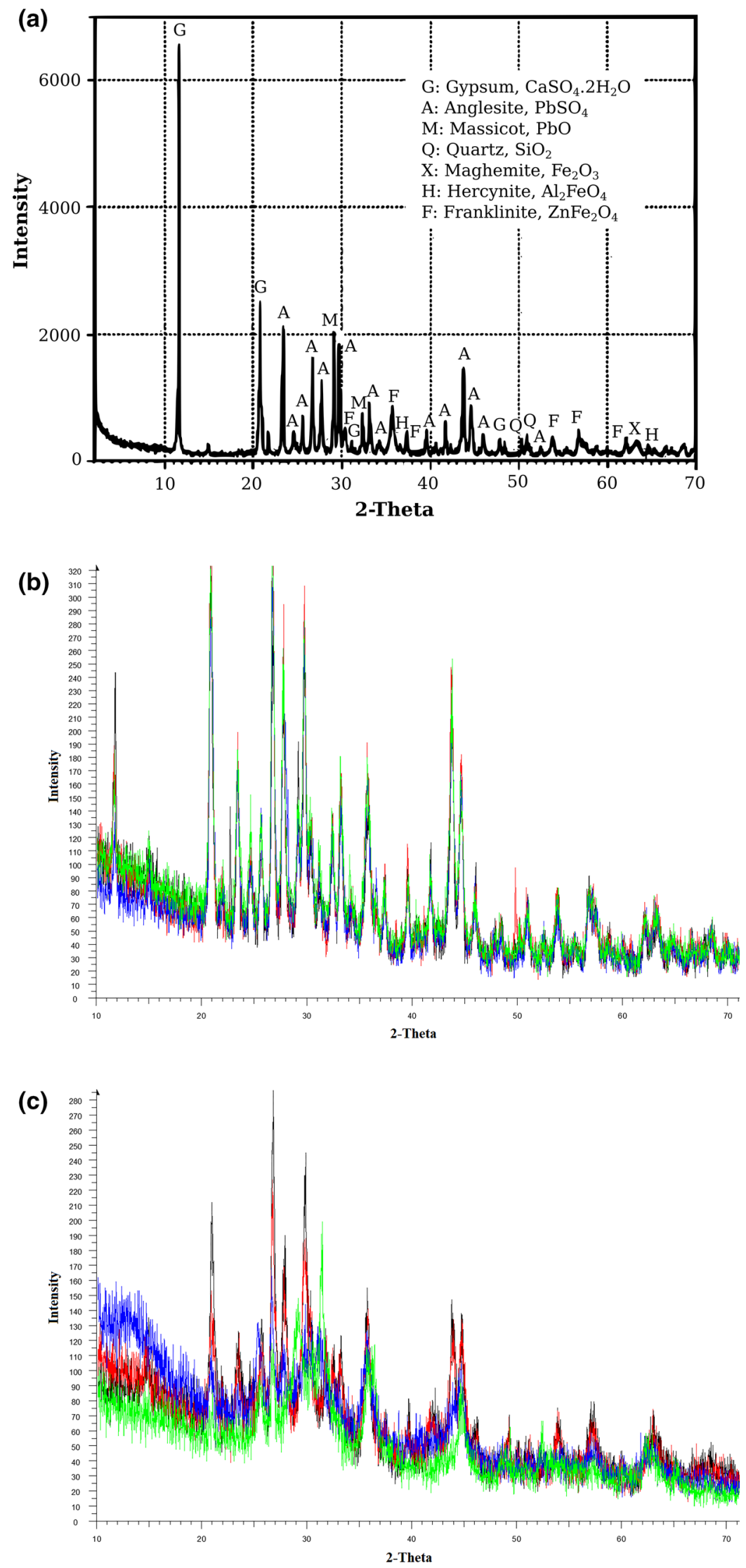
Fig. 4 SEM images of milled samples, a VBM b RM (a)
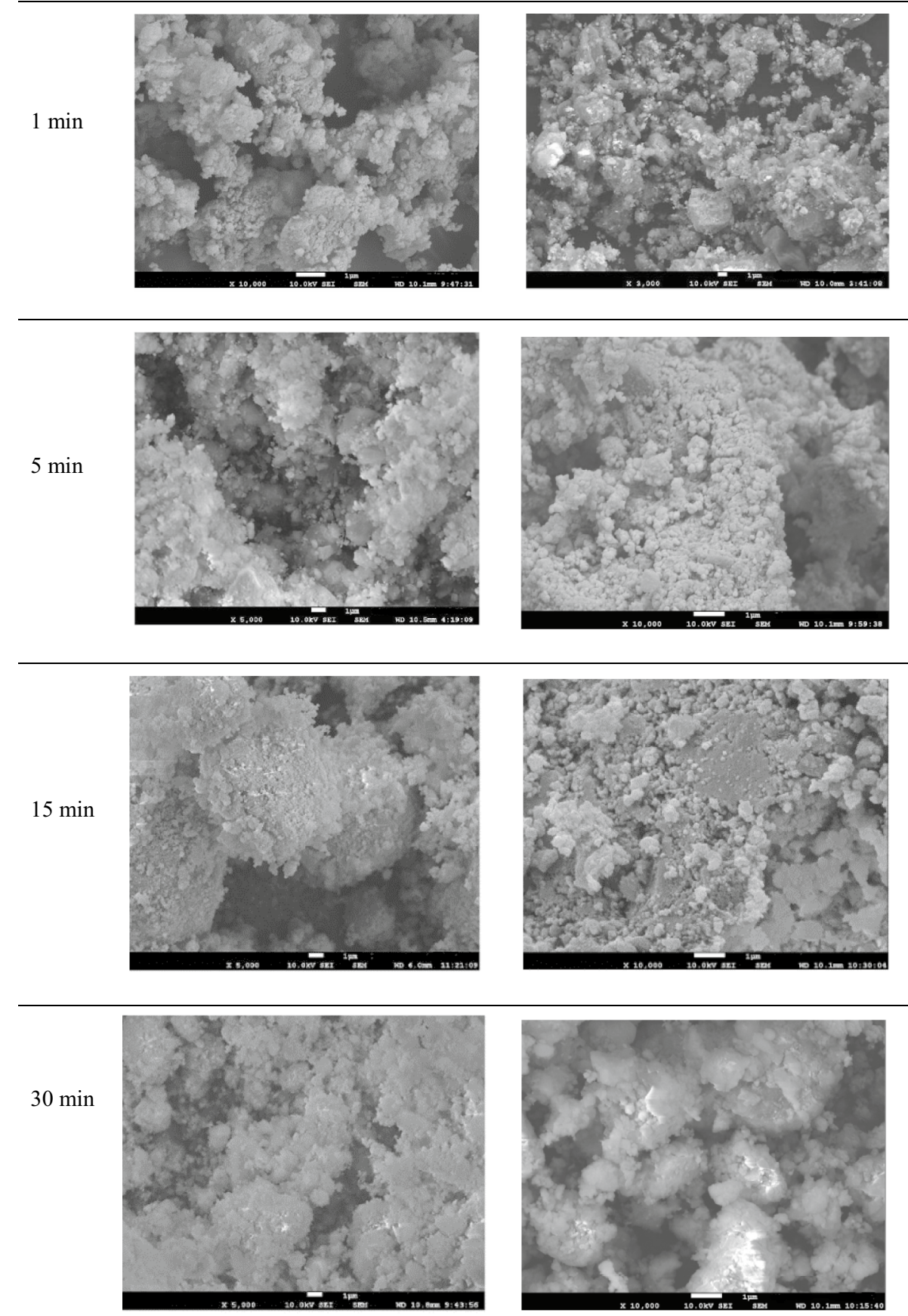

Distribution) analysis of samples ground at both mills for different times was carried out. The obtained results are seen in Table 2.

Decrease in particle size, which occurred in material depending on grinding time, leads to increase in surface area. Thus, since the reaction surface of the milled material increases as well as its surface area increasing during the leaching, an increase is expected in extraction efficiency. $\mathrm{N}_{2}$-BET surface area measurements of ZCR milled for different times were made to understand better this process. The obtained results are seen in Table 3 . As seen in the table, while an increase is expected in surface area through the increasing grinding time, it was understood that a decrease occurred. The probable cause for this condition to be examined is thought to be grain growth related to agglomeration that happened. Data supporting particle growth are also available in SEM images, especially small particles seem to stick to larger ones. The difference between the mills is 
Table 2 Particle size

distribution of original ZCR and milled ZCR by VBM and RM at different time

\begin{tabular}{|c|c|c|c|c|c|c|}
\hline \multirow[t]{2}{*}{ Grinding time (min) } & \multicolumn{3}{|c|}{$\mathrm{VBM}(\mu \mathrm{m})$} & \multicolumn{3}{|c|}{$\mathrm{RM}(\mu \mathrm{m})$} \\
\hline & $d(0.1)$ & $d(0.5)$ & $d(0.9)$ & $d(0.1)$ & $d(0.5)$ & $d(0.9)$ \\
\hline Original & 3.176 & 24.706 & 410.834 & 3.176 & 24.706 & 410.834 \\
\hline 1 & 2.267 & 22.700 & 88.661 & 1.750 & 13.290 & 73.099 \\
\hline 5 & 1.939 & 19.536 & 78.494 & 2.709 & 29.993 & 355.074 \\
\hline 15 & 1.897 & 18.380 & 146.370 & 2.753 & 27.059 & 122.919 \\
\hline 30 & 2.317 & 31.368 & 325.613 & 2.886 & 25.747 & 124.720 \\
\hline
\end{tabular}

Table $3 \mathrm{~N}_{2}$-BET of original ZCR and milled ZCR by VBM and $\mathrm{RM}$ at different time

\begin{tabular}{lllllrr}
\hline & Grinding time $(\mathrm{min})$ & Original & 1 & 5 & 15 & 30 \\
\hline VBM & Specific surface are $\left(\mathrm{m}^{2} / \mathrm{g}\right)$ & 28.40 & 17.4 & 13 & 11.5 & 10.5 \\
RM & & & 8.7 & 7.6 & 5.5 & 6.0 \\
\hline
\end{tabular}

thought to be due to the different impact forces the grinding systems have on the particle.

\section{Leaching results}

ZCR samples were milled in two different mill systems and the original ZCR samples were leached using sulfuric acid. Franklinite $\left(\mathrm{ZnFe}_{2} \mathrm{O}_{4}\right)$ structure of some of zinc contained within ZCR and the leach reactions of metals in different forms are as follows:
$\mathrm{ZnO}+\mathrm{H}_{2} \mathrm{SO}_{4} \rightarrow \mathrm{ZnSO}_{4}+\mathrm{H}_{2} \mathrm{O}$

$\mathrm{ZnFe}_{2} \mathrm{O}_{4}+4 \mathrm{H}_{2} \mathrm{SO}_{4} \rightarrow \mathrm{ZnSO}_{4}+\mathrm{Fe}_{2}\left(\mathrm{SO}_{4}\right)_{3}+4 \mathrm{H}_{2} \mathrm{O}$,

$\mathrm{PbO}+\mathrm{H}_{2} \mathrm{SO}_{4} \rightarrow \mathrm{PbSO}_{4}+\mathrm{H}_{2} \mathrm{O}$

$\mathrm{Fe}_{2} \mathrm{O}_{3}+3 \mathrm{H}_{2} \mathrm{SO}_{4} \rightarrow \mathrm{Fe}_{2}\left(\mathrm{SO}_{4}\right)_{3}+3 \mathrm{H}_{2} \mathrm{O}$

As seen from the reactions above, it is seen that in a leaching carried out with a sulfuric acid, it is possible for
Fig. 5 Effect of two different milling system, milling time, and leaching temperature on the $\mathrm{Zn}$ recovery from $\mathrm{ZCR}\left[\mathrm{H}_{2} \mathrm{SO}_{4}\right.$ concentration: $0.5 \mathrm{M}$, leaching time: $30 \mathrm{~min}$, stirring speed: $400 \mathrm{rpm}$, liquid/solid ratio: $25 \mathrm{~mL} / \mathrm{g},(\mathrm{H}):$ ZCR milled by VBM, $(\mathrm{O})$ : original ZCR, $(\mathrm{R})$ : ZCR milled by RM]
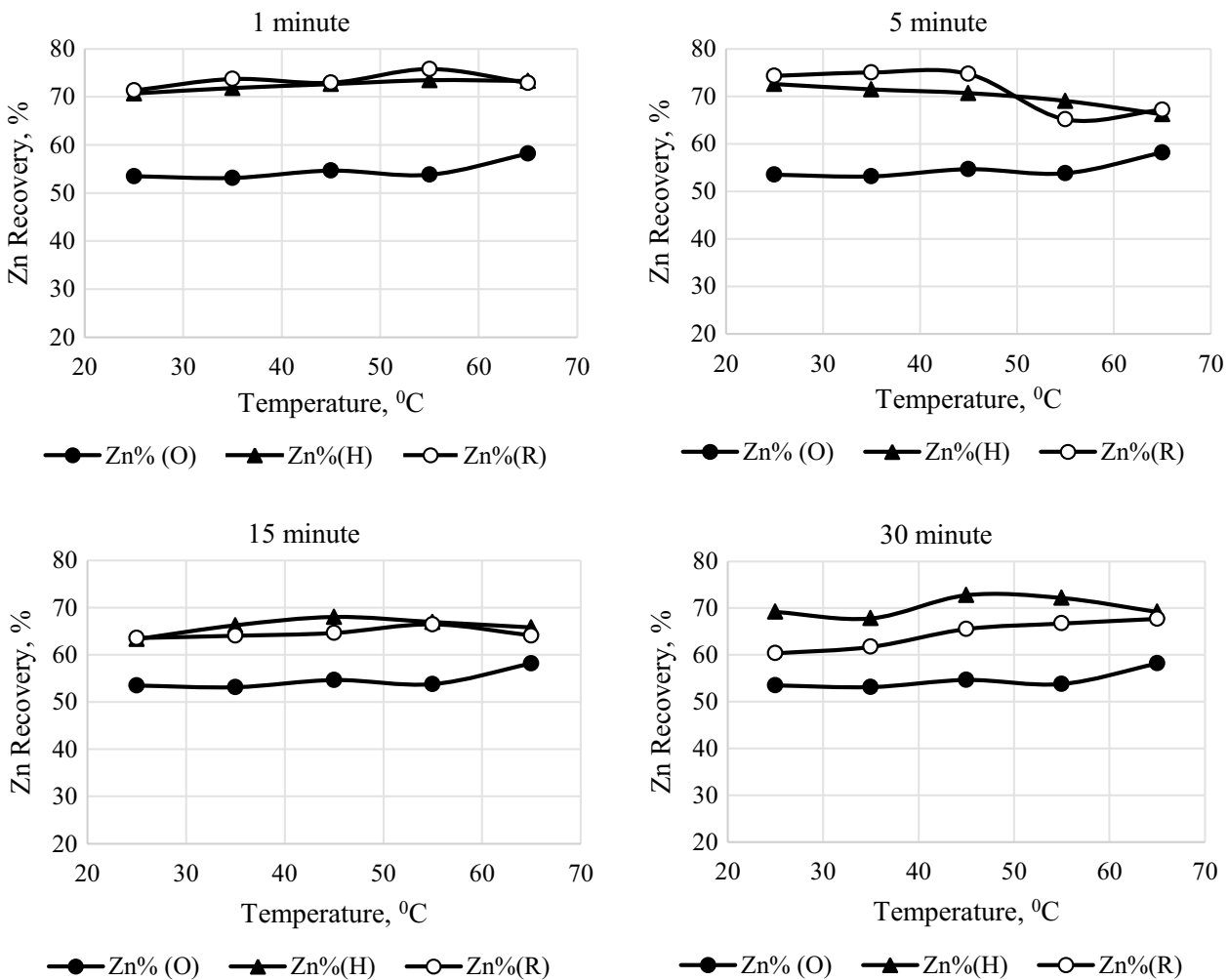
lead and iron, along with zinc, to pass to solution in their sulfate forms. However, low solubility of the occurring sulfate $\left(\mathrm{PbSO}_{4}\right)$ means the leaching is partly selective (Gündüz, 1985 ), in fact, it is stated that solubility of lead sulfate compound is such a low value as $1.87 \times 10^{-8}$, according to the literature information (Lide 1991).

Effect of grinding time on extraction of zinc contained within ZCR through sulfuric acid was examined in the range of 1-30 min at two different mills and effect of leach temperature was examined in the range of $\left(25-65^{\circ} \mathrm{C}\right)$. The obtained results are seen in Fig. 5.

As seen in the figure, it is understood that metal extraction efficiency does not change much in general through the increasing leach temperature. Under the current experimental conditions, $\mathrm{Ag}$ and $\mathrm{Pb}$ were determined not to pass to solution. On the other hand, advanced grinding procedure is seen to cause a certain increase in $\mathrm{Zn}$ extraction.

The fact that leach parameters are in $0.5 \mathrm{M} \mathrm{H}_{2} \mathrm{SO}_{4}$ concentration, leach time is such a short time as $30 \mathrm{~min}$ and metal extraction values obtained at room temperature are high, there has been an apparent increase in metal extraction values when compared to results obtained in studies carried out over samples with the original grain size is very important to reveal the contribution of grinding.

While metal extraction efficiency is expected to increase through the increasing grinding time, it is seen in the obtained graphics that the mentioned expectation has not happened. Probable explanation of this condition commonly encountered in mechanical activation procedures can be explained by the fact that grain size of particle first decreases through the increasing grinding time and later an increase occurs in particle size due to the occurring agglomeration and accordingly, leach efficiency remains stable and/or decreases (Balaz 2000).

This approach is supported by the fact that BET surface area values decrease though the increasing grinding time in the data shown in Tables 2 and 3, which show particle size distribution of materials obtained for different grinding times.

Effect of leach time (5-120 min) was examined together with effect of grinding time (1-5 min) (Fig. 6). In the
Fig. 6 Effect of two different milling system, milling time, and leaching time on the $\mathrm{Zn}$ recovery from $\mathrm{ZCR}\left[\mathrm{H}_{2} \mathrm{SO}_{4}\right.$ concentration: $0.5 \mathrm{M}$, leaching temperature: $25^{\circ} \mathrm{C}$, stirring speed: $400 \mathrm{rpm}$, liquid/solid ratio: $25 \mathrm{~mL} / \mathrm{g},(\mathrm{H})$ : ZCR milled by VBM, $(\mathrm{O})$ : original ZCR, (R): ZCR milled by RM]
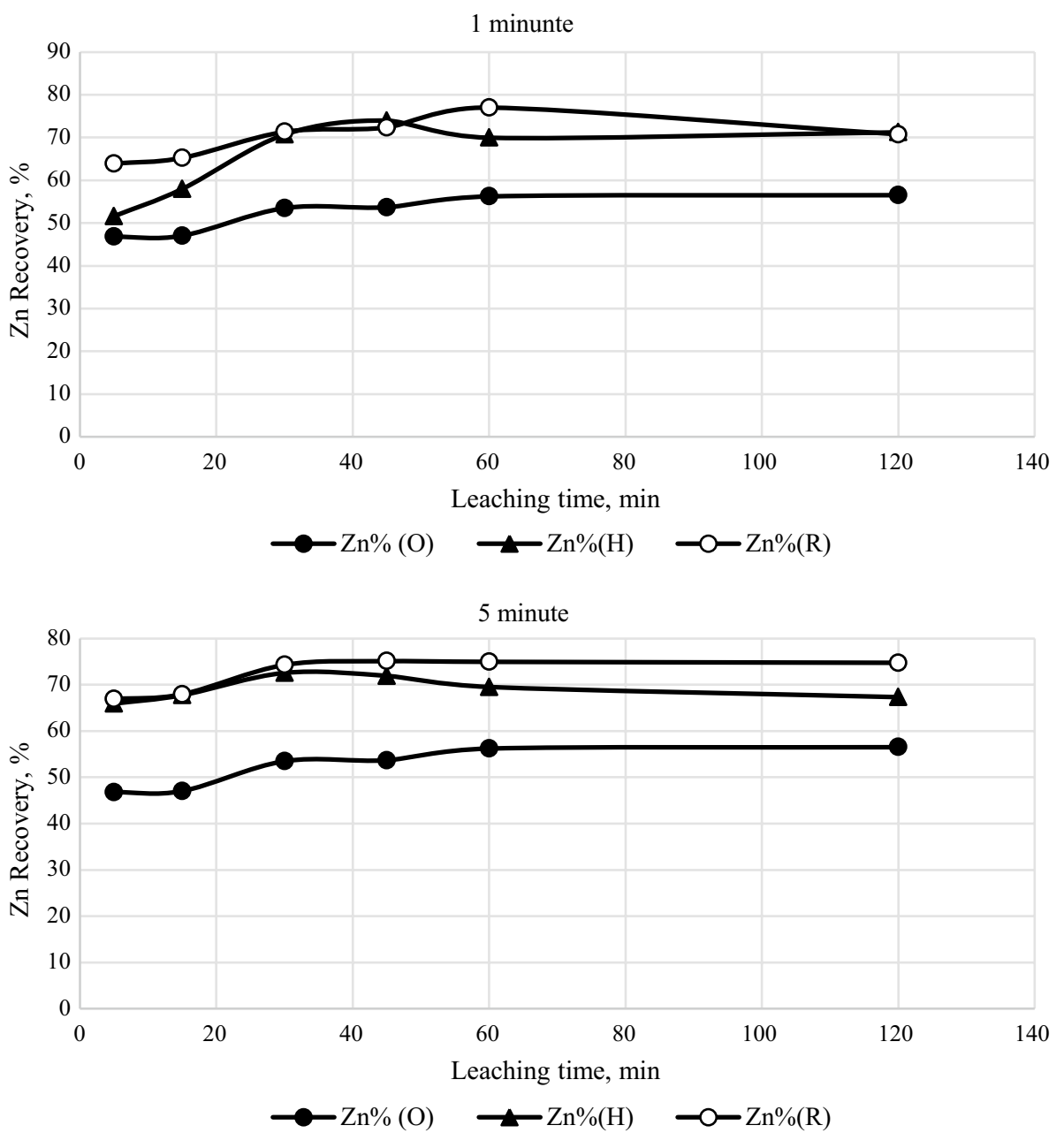
figure, the increase seen in metal extraction value through the increasing leach time is understood to decrease a little through the increasing grinding time. However, when compared to leach results of the original ZCR, it is seen that an increase has occurred in zinc passing to solution in all the samples.

In Fig. 7, effect of liquid-solid rate on metal extraction from ZCR and the leach results of samples obtained at VBM and RM for grinding time of, respectively, 1 and $5 \mathrm{~min}$ are seen. In the figure, it is seen that very high amount of zinc can be extracted under experimental conditions containing excessive liquid-solid rate.

Effects of liquid-solid rate and of sulfuric acid concentration on metal extraction from ZCR milled for $5 \mathrm{~min}$ were examined together (Fig. 8). According to the obtained results, it is seen that an increase comparatively occurred in metal extraction values through the increasing acid concentration. However, it was determined in experiments done in high acid concentrations that the rheological properties of leaching environment changed and some problems, such as particularly filtration, emerged.

\section{Conclusion}

In the preset study, opportunities for regaining zinc from zinc metal production process residual (ZCR) have been investigated. Within this scope, the mentioned plant residual was subjected to the mechanical activation procedures at vibrating ball mill (VBM) and ring mill (RM) and the obtained samples were leached under different conditions. Characterization of samples of the original ZCR, milled at two different mills, was examined using various analysis methods. The important results obtained in the studies carried out can be sorted as follows:

1- The obtained ZCR was used in experiments without being subjected to any preliminary preparation procedure to represent establishing conditions of studies carried out over it.

2- In chemical analysis of ZCR, it was determined that it contains a significant amount of zinc, lead, iron and silver. It was determined as a result of mineralogical analysis carried out that plant residual consists of mostly
Fig. 7 Effect of two different milling system, milling time, and liquid-solid ratio on the $\mathrm{Zn}$ recovery from $\mathrm{ZCR}\left[\mathrm{H}_{2} \mathrm{SO}_{4}\right.$ concentration: $0.5 \mathrm{M}$, leaching temperature: $25^{\circ} \mathrm{C}$, stirring speed: $400 \mathrm{rpm}$, leaching time: $30 \mathrm{~min},(\mathrm{H})$ : ZCR milled by VBM, (O): original ZCR, (R): ZCR milled by RM]
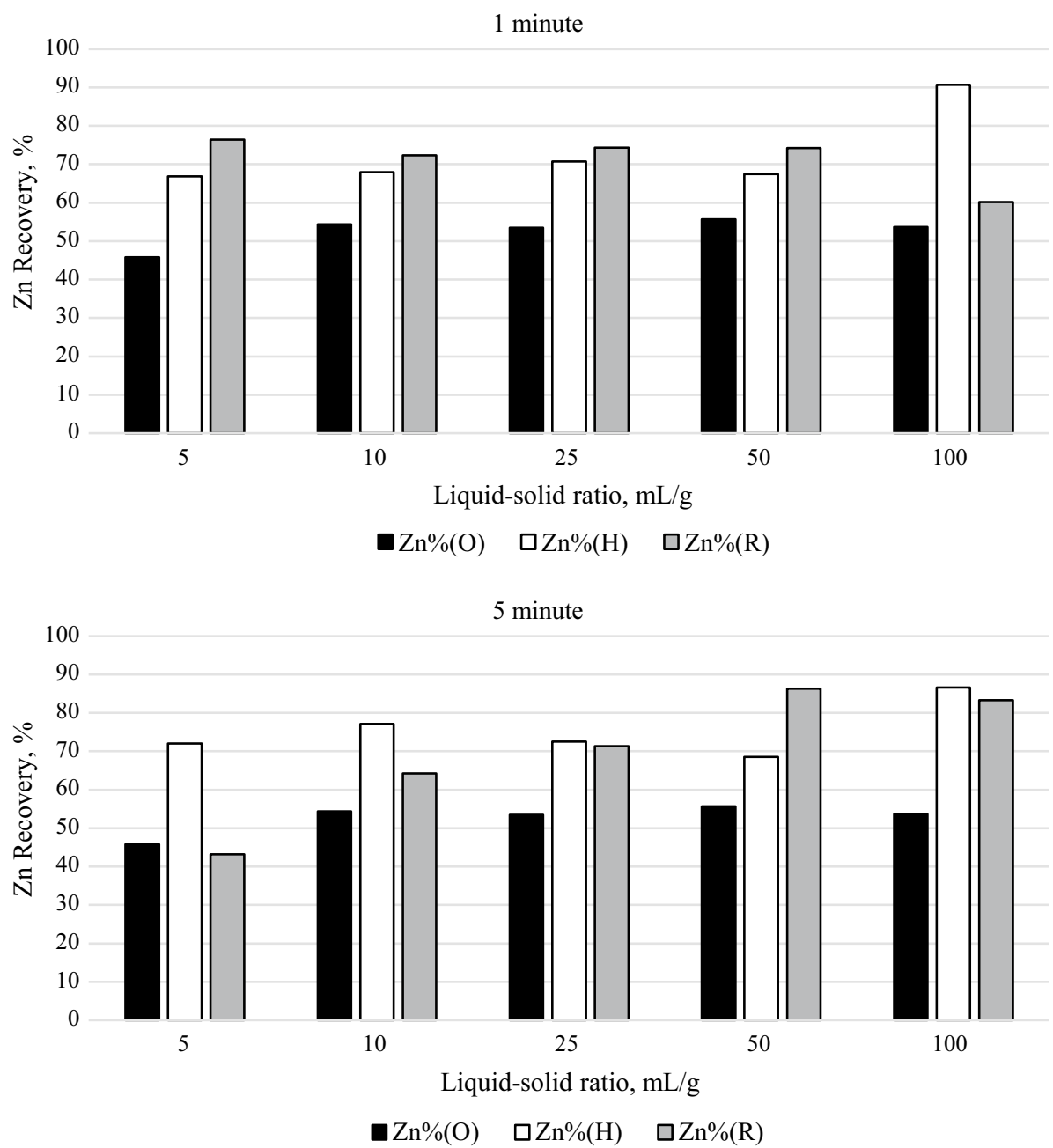

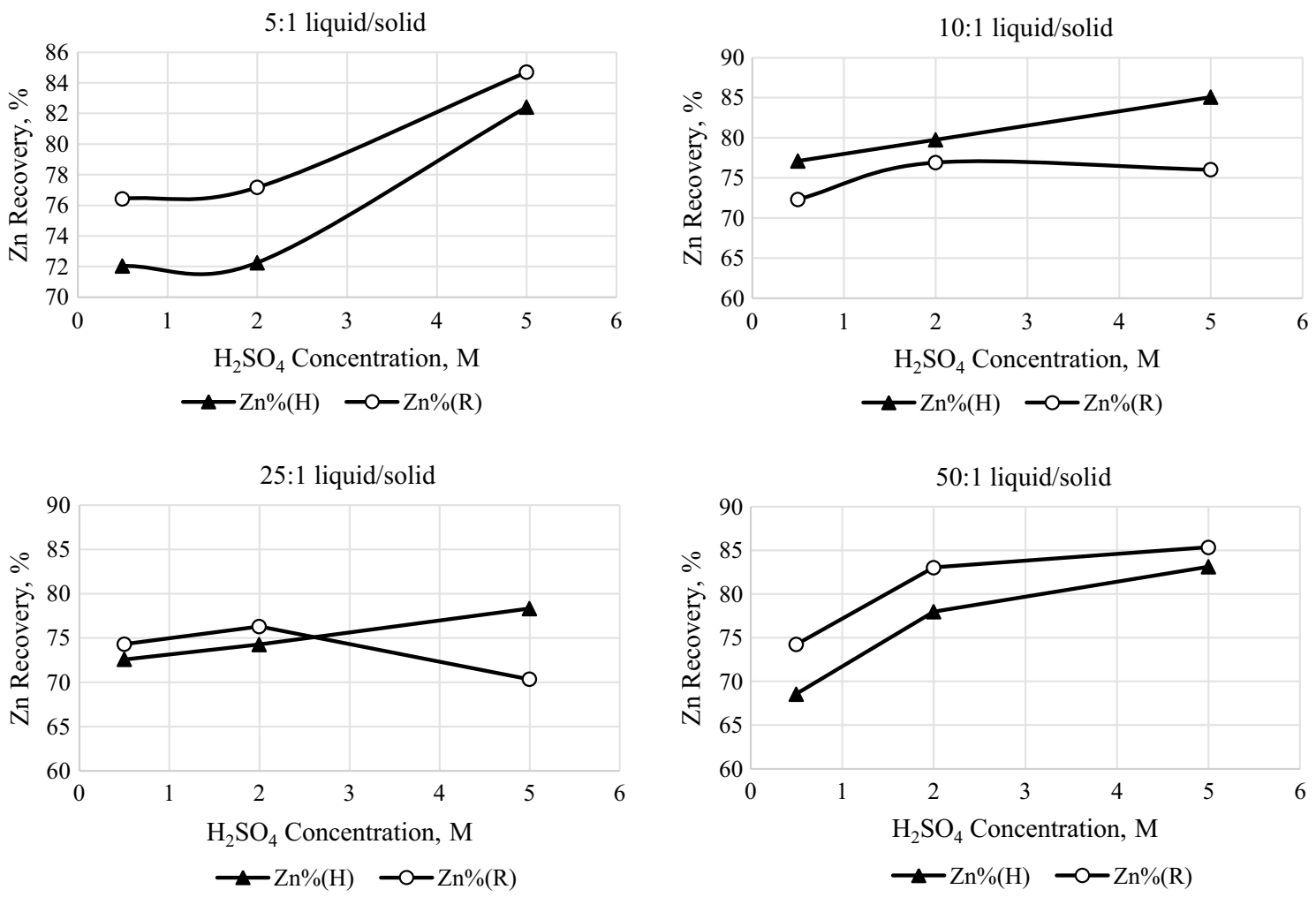

Fig. 8 Effect of two different milling system, acid concentration, and liquid-solid ratio on the $\mathrm{Zn}$ recovery from ZCR [Leaching time: 30 min, leaching temperature: $25^{\circ} \mathrm{C}$, stirring speed: $400 \mathrm{rpm}$, milling

time: 5 min, $(\mathrm{H})$ : ZCR milled by VBM, $(\mathrm{O})$ : original ZCR, $(\mathrm{R})$ : ZCR milled by RM]

$\mathrm{CaSO}_{4} \cdot 2 \mathrm{H}_{2} \mathrm{O}$ and $\mathrm{PbSO}_{4}$ mineral phases and zinc is in the form of Franklinite $\left(\mathrm{ZnFe}_{2} \mathrm{O}_{4}\right)$.

3- Samples of ZCR, obtained as a result of grinding at VBM and RM, were characterized. When the peaks obtained in XRD analysis carried out were compared with the peaks of the original samples, it was revealed that there were significant changes in peak intensity of samples obtained in two different grinding systems.

4- According to particle size distribution analyses of samples obtained as a result of grinding ZCR at VBM and $\mathrm{RM}$, while a decrease is expected in particle size through the increasing grinding time, grains sizes of particles were determined to increase for a grinding time of over $1 \mathrm{~min}$. According to comparative characterization analyses of the ground samples, it was determined that through the increasing grinding time, particles became agglomerated and an increase in grain size occurred. While average grain size of the original sample was $d(0.9)=410.834 \mu \mathrm{m}$, it was determined that average grain size of sample milled at VBM for 1-30 min was 88.661$325.613 \mu \mathrm{m}$ and average grain size of sample ground at $\mathrm{RM}$ for the same grinding time was 73.099-124.720 $\mu \mathrm{m}$. On the other hand, the result that $\mathrm{N}_{2}$-BET surface area of the milled samples decreased through the increasing

grinding time and the fact that small particles seen in SEM analyses held on to partly big parts supports the idea that particles became agglomerated.

5- The fact that the solubility of compound of sulfuric acid with lead contained within is very low and lead remains solid shows the leaching is partly selective. It was determined according to the obtained results that leach efficiency of samples obtained as a result of advanced grinding/mechanical activation procedures was higher than the results obtained from leach of the original samples. However, it was determined that metal extraction values obtained from leach of samples milled at both mills did not change through the increasing grinding time. While zinc extraction values, obtained in experiments carried out in $0.5 \mathrm{M} \mathrm{H}_{2} \mathrm{SO}_{4}$ concentration, leach time of $30 \mathrm{~min}$ and at leach temperature of $25^{\circ} \mathrm{C}$, under the solid-liquid rate of $1 / 25$ and $1 / 100$, of the samples that were obtained as a result of grinding time of $1 \mathrm{~min}$ at VBM were, respectively, $70 \%$ and $90 \%$, zinc extraction values obtained as a result of leaching of the original samples under the same conditions were determined to be $52 \%$ and $54 \%$. Under experimental conditions, under which RM was used under similar conditions, zinc extraction values were determined to be $74 \%$ and $60 \%$. 
Acknowledgements This study was supported by the TUBITAK (Scientific and Technological Research Council of Turkey) under the Project No: 112M285.

\section{Compliance with ethical standards}

Conflict of interest The author declares no conflict of interest.

Open Access This article is licensed under a Creative Commons Attribution 4.0 International License, which permits use, sharing, adaptation, distribution and reproduction in any medium or format, as long as you give appropriate credit to the original author(s) and the source, provide a link to the Creative Commons licence, and indicate if changes were made. The images or other third party material in this article are included in the article's Creative Commons licence, unless indicated otherwise in a credit line to the material. If material is not included in the article's Creative Commons licence and your intended use is not permitted by statutory regulation or exceeds the permitted use, you will need to obtain permission directly from the copyright holder. To view a copy of this licence, visit http://creativecommons.org/licenses/by/4.0/.

\section{References}

Ashtari P, Pourghahramani P (2015) Selective mechanochemical alkaline leaching of zinc from zinc plant residue. Hydrometallurgy 156:165-172

Baláž P (2000) Extractive metallurgy of activated minerals. 1st edn. Elsevier Science B.V., Amsterdam. ISBN: 044450206 8: 9-124

Baláž P, Boldizarova E, Achimovicova M, Kammel R (2000) Leaching and dissolution of a pentlandite concentrate pretreated by mechanical activation. Hydrometallurgy 57:85-96

Charlot F, Gaffet E, Zeghmati B, Bernard F, Niepce JC (1999) Mechanically activated synthesis studied by $\mathrm{X}$-ray diffraction in the $\mathrm{Fe}-\mathrm{Al}$ system. Mat Sci Eng A 262:279-288

Chen G, Chen J, Peng J (2015) Effects of mechanical activation on structural and microwave absorbing characteristics of high titanium slag. Powder Technol 286:218-222

Fattahi A, Rashchi F, Abkhoshk E (2016) Reductive leaching of zinc, cobalt and manganese from zinc plant residue. Hydrometallurgy 161:185-192

Gündüz T (1985) Yar1-Mikro Kalitatif Analiz, Ankara University, Science Faculty Publications, page: 230, Ankara-Turkey (In Turkish language)

Haug TA (2010) Dissolution and carbonation of mechanically activated olivine-Investigating $\mathrm{CO}_{2}$ sequestration possibilities, Thesis for the degree of Philosophiae Doctor, Norwegian University of Science and Technology, ISBN 978-82-471-1960-0 (printed ver.): 25-26

Jiang G, Peng B, Liang Y, Chai L, Wang Q, Li Q, Hu M (2017) Recovery of valuable metals from zinc leaching residue by sulfate roasting and water leaching. Trans Non Metals Soc China 27:1180-1187
Langová Š, Leško J, Matýsek D (2009) Selective leaching of zinc from zinc ferrite with hydrochloric acid. Hydrometallurgy 95:179-182

Li YC, Zhuo SN, Peng B, Min XB, Liu H, Ke Y (2020) Comprehensive recycling of zinc and iron from smelting waste containing zinc ferrite by oriented transformation with SO2. J Cleaner Prod 263:121468

Lide DR (1991) CRC Handbook of chemistry and physics, 72nd edn. CRC Pres Inc., Boston, p 48

Nunez C, Vinals J (1984) Kinetics of leaching of zinc ferrite in aqueous hydrochloric acid solutions. Metall Mater Trans B 15:221-228

Pourghahramani P, Akhgar BN (2015) Characterization of structural changes of mechanically activated natural pyrite using XRD line profile analysis. Int J Min Proc 134:23-28

Raghavan R, Mohanan PK, Patnaik SC (1998) Innovative processing technique to produce zinc concentrate from zinc production residue with simultaneous recovery of lead and silver. Hydrometallurgy 48:225-237

Ru Z, Pan C, Liu G, Wang X, Dou G, Zhu K (2015) Leaching and recovery of zinc from leaching residue of zinc calcine based on membrane filter press. Trans Non Metals Soc China 25:622-627

Sethurajan M, Huguenot D, Jain R, Lens PNL, Horn HA, Figueiredo LHA, Hullebusch ED (2017) Leaching and selective zinc recovery from acidic leachates of zinc metallurgical leach residues. J Hazard Mat 324:71-82

Silwamba M, Ito M, Hiroyoshi N, Tabelin CB, Hashizume R, Fukushima T, Park I, Jeon S, Igarashi T, Sato T, Chirwa M, Banda K, Nyambe I, Nakata H, Nakayama S, Ishizuka M (2020) Recovery of lead and zinc from zinc plant leach residues by concurrent dissolution cementation using zero-valent aluminum in chloride medium. Metals 10:2-15

Tan Q, Deng C, Li J (2016) Innovative application of mechanical activation for rare earth elements recovering: process optimization and mechanism exploration. Sci Rep 19961(6):1-10

Tokumitsu K (1997) Reduction of metal oxides by mechanical alloying method. Solid State Ionics 101-103:25-31

Turan MD, Altundoğan HS, Tümen F (2004) Recovery of zinc and lead from zinc plant residue. Hydrometallurgy 75:169-176

Turan MD, Altundoğan HS, Boyrazlı M, Sarı ZA, Nizamoğlu H, Demiraslan A (2019) Basic leaching behavior of mechanically activated zinc plant residue. Trans Indian Inst Metals 72(9):2359-2364

Xia DK, Pickles CA (1999) Kinetics of zinc ferrite leaching in caustic media in the deceleratory period. Miner Eng 12(6):693-700

Xiuying G, Dong X, Guanghong D, Peng M (2010) A review of mechanochemistry applications in waste management. Waste Manage 30:4-10

Zhang C, Zhuang L, Wang J, Bai J, Yuan W (2016) Extraction of zinc from zinc ferrites by alkaline leaching: enhancing recovery by mechanochemical reduction with metallic iron. J Southern African Inst Min Metall 116:1111-1114

Zhao Z, Zhang Y, Chen X, Chen A, Huo G (2009) Effect of mechanical activation on the leaching kinetics of pyrrhotite. Hydrometallurgy 99:105-108

Publisher's Note Springer Nature remains neutral with regard to jurisdictional claims in published maps and institutional affiliations. 